Article

\title{
Guanidine Alkaloids from the Marine Sponge Monanchora pulchra Show Cytotoxic Properties and Prevent EGF-Induced Neoplastic Transformation in Vitro
}

\author{
Sergey A. Dyshlovoy ${ }^{1,2,3, *}$, Kseniya M. Tabakmakher ${ }^{2}$, Jessica Hauschild ${ }^{1}$, \\ Regina K. Shchekaleva ${ }^{2}$, Katharina Otte ${ }^{1}$, Alla G. Guzii ${ }^{2}$, Tatyana N. Makarieva ${ }^{2}$, \\ Ekaterina K. Kudryashova ${ }^{2}$, Sergey N. Fedorov ${ }^{2}$, Larisa K. Shubina ${ }^{2}$, Carsten Bokemeyer ${ }^{1}$, \\ Friedemann Honecker 1,4, Valentin A. Stonik ${ }^{2,+}$ and Gunhild von Amsberg 1,+ \\ 1 Laboratory of Experimental Oncology, Department of Oncology, Hematology and Bone Marrow \\ Transplantation with Section Pneumology, Hubertus Wald-Tumorzentrum, University Medical Center \\ Hamburg-Eppendorf, Martinistrasse 52, Hamburg 20246, Germany; j.hauschild@uke.de (J.H.); \\ k.otte@uke.de (K.O.); c.bokemeyer@uke.de (C.B.); friedemann.honecker@zetup.ch (F.H.); \\ g.von-amsberg@uke.de (G.v.A.) \\ 2 Laboratory of Marine Natural Products Chemistry, G.B. Elyakov Pacific Institute of Bioorganic Chemistry, \\ Far-East Branch, Russian Academy of Sciences, Prospect 100-let Vladivostoku 159, Vladivostok 690022, \\ Russia; xen-tab@yandex.ru (K.M.T.); flagmandv@inbox.ru (R.K.S.); gagry@rambler.ru (A.G.G.); \\ makarieva@piboc.dvo.ru (T.N.M.); catrinog.81@mail.ru (E.K.K.); fedorov@piboc.dvo.ru (S.N.F.); \\ shubina@piboc.dvo.ru (L.K.S.); stonik@piboc.dvo.ru (V.A.S.) \\ 3 School of Natural Sciences, Far Eastern Federal University, Sukhanova Street 8, Vladivostok 690091, Russia \\ 4 Tumor and Breast Center ZeTuP St. Gallen, Rorschacher Strasse 150, St. Gallen 9006, Switzerland \\ * Correspondence: dyshlovoy@gmail.com; Tel.: +49-40-7410-51950 or +7-423-231-1168 \\ + These authors contributed equally to this work.
}

Academic Editor: Kirsten Benkendorff

Received: 18 May 2016; Accepted: 8 July 2016; Published: 15 July 2016

\begin{abstract}
Guanidine alkaloids from sponges Monanchora spp. represent diverse bioactive compounds, however, the mechanisms underlying bioactivity are very poorly understood. Here, we report results of studies on cytotoxic action, the ability to inhibit EGF-induced neoplastic transformation, and the effects on MAPK/AP-1 signaling of eight rare guanidine alkaloids, recently isolated from the marine sponge Monanchora pulchra, namely: monanchocidin A (1), monanchocidin B (2), monanchomycalin C (3), ptilomycalin A (4), monanchomycalin B (5), normonanchocidin D (6), urupocidin A (7), and pulchranin A (8). All of the compounds induced cell cycle arrest (apart from 8) and programmed death of cancer cells. Ptilomycalin A-like compounds 1-6 activated JNK1/2 and ERK1/2, following AP-1 activation and caused p53-independent programmed cell death. Compound 7 induced p53-independent cell death without activation of AP-1 or caspase-3/7, and the observed JNK1/2 activation did not contribute to the cytotoxic effect of the compound. Alkaloid 8 induced JNK $1 / 2$ (but not ERK1/2) activation leading to p53-independent cell death and strong suppression of AP-1 activity. Alkaloids 1-4, 7, and $\mathbf{8}$ were able to inhibit the EGF-induced neoplastic transformation of JB6 $\mathrm{P}^{+} \mathrm{Cl} 41$ cells. Our results suggest that investigated guanidine marine alkaloids hold potential to eliminate human cancer cells and prevent cancer cell formation and spreading.
\end{abstract}

Keywords: guanidine alkaloids; monanchocidin A; Monanchora pulchra; apoptosis; MAPK; AP-1; neoplastic transformation 


\section{Introduction}

Guanidine alkaloids from sponges belonging to the genus Monanchora represent compounds with diverse chemical structures and a broad spectrum of biological activities [1-6]. Some of these compounds are cytotoxic against different types of human cancer cells [7-13]. Recently, we have reported on one of these compounds, monanchocidin A, to possess a unique and novel combination of properties. Remarkably, we have identified an unusual mode of action mediating the observed cytotoxic activity $[8,10,14]$ of this natural compound: thus, monanchocidin A was able to induce cytotoxic autophagy (type II programmed cell death) and lysosomal membrane permeabilization (LMP) in human germ cell tumor cells [14]. In addition, it exhibited anti-migratory activity at low non-cytotoxic concentrations [15]. At the same time, the classical apoptosis, which is frequently activated by conventional chemotherapies and which has been initially suggested as a main mechanism of monanchocidin A cytotoxicity [8], was of minor importance in this case [14].

In addition to monanchocidin A, very little is known on bioactivity, and literally nothing is known on the mechanisms of action of other guanidine alkaloids from marine sponges Monanchora spp. Ptilomycalin A (4) has been initially isolated by Kashman et al. in 1989 from the Caribbean sponges Ptilocausis spiculifer and from a Red Sea sponge Hemimycale sp. [16]. Recently, we were able to isolate it from the marine sponge Monanchora pulchra [17]. This alkaloid has shown a potent cytotoxicity against a broad panel of human cancer cells [16,18-20]. However, to date molecular targets and the mode of action of ptilomycalin A in mammalian cell have not been studied. For compounds 2, 3, and 5-8, isolation and preliminary results on cytotoxicities have been recently reported by us [9-11,17,21,22]. However, no data on their mode of cytotoxic action are available so far.

Crambescidin alkaloids are another group of natural guanidine alkaloids structurally related to ptilomycalin A. Crambescidins are cytotoxic against different human cancer cells, as well as yeast cells, and induce cell cycle arrest [23-25]. They induce differentiation of K562 chronic myelogenous leukemia cells [23] and block $\mathrm{Ca}^{2+}, \mathrm{Na}^{+}$, and $\mathrm{K}^{+}$channels [26,27]. Recently, Rubiolo et al. reported the results of transcriptomic analysis of HepG2 human cancer cells treated with crambescidin-816 at non-cytotoxic concentrations [28]. They were able to demonstrate a decreased cancer cell migration by inhibition of cell-cell and cell-matrix adhesion, a reduced tight junctions formation, and the alteration of cytoskeleton dynamics [28].

In continuation of our study of marine compounds possessing potential cancer-preventive, cytotoxic and anti-cancer properties [29-38], we investigated the in vitro activity and mode of action of eight rare marine guanidine alkaloids, which have recently been isolated in our laboratory from the marine sponge Monanchora pulchra, namely: monanchocidin A (Mc-A, 1) [8], monanchocidin B (Mc-B, 2) [10], monanchomycalin C (Mm-C, 3) [17], ptilomycalin A (Pt-A, 4) [16], monanchomycalin B (Mm-B, 5) [9], and normonanchocidin D (nMc-D, 6) [22], urupocidin A (Ur-A, 7) [21], and pulchranin A (Pch-A, 8) [11] (Figure 1A). Here, we report the in vitro cancer chemo-preventive properties, the cytotoxic activities, and the effects on MAPK/AP-1 signaling and associated pathways.

This study is the very first report on molecular effects of monanchocidin B (2), monanchocidin C (3), ptilomycalin A (4), monanchomycalin B (5), normonanchocidin D (6), urupocidin A (7), and pulchranin A (8) in cancer cells. 
(A)
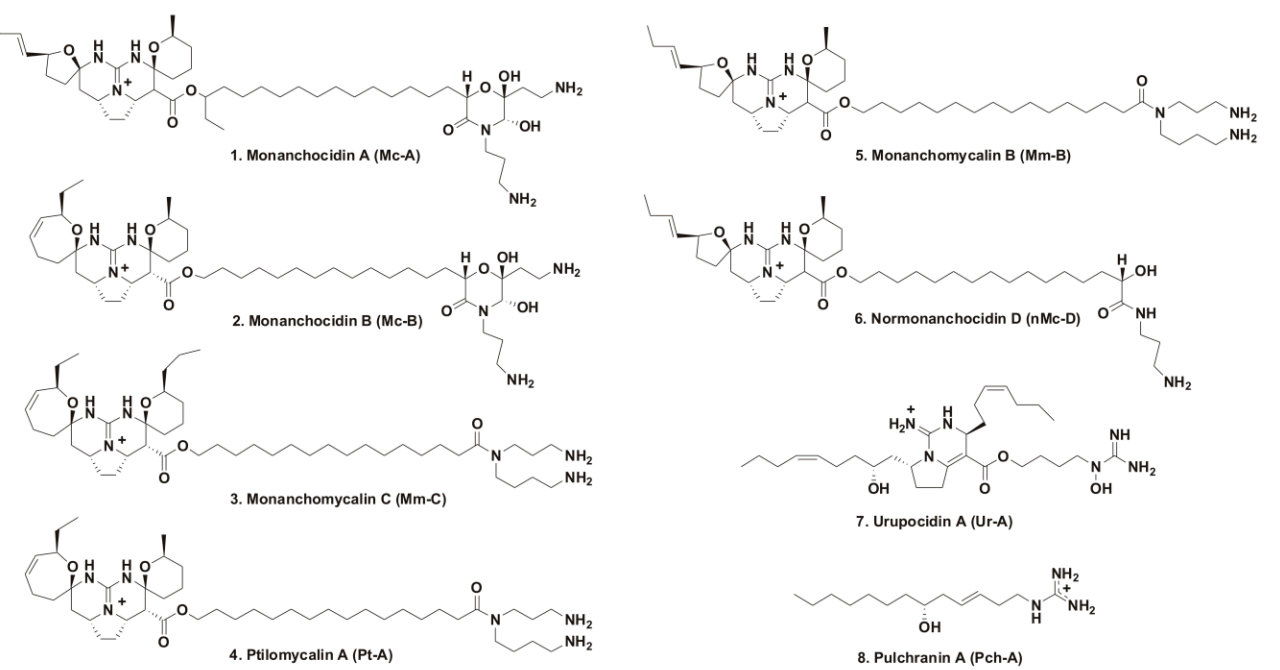

(B)

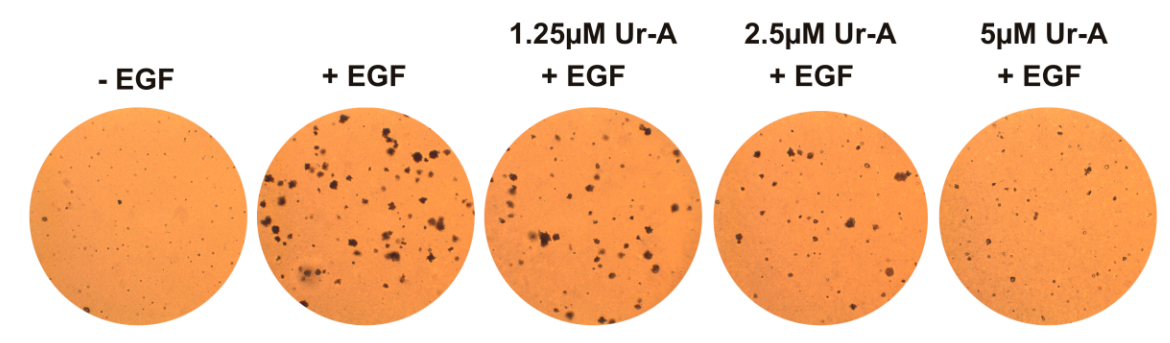

(C)
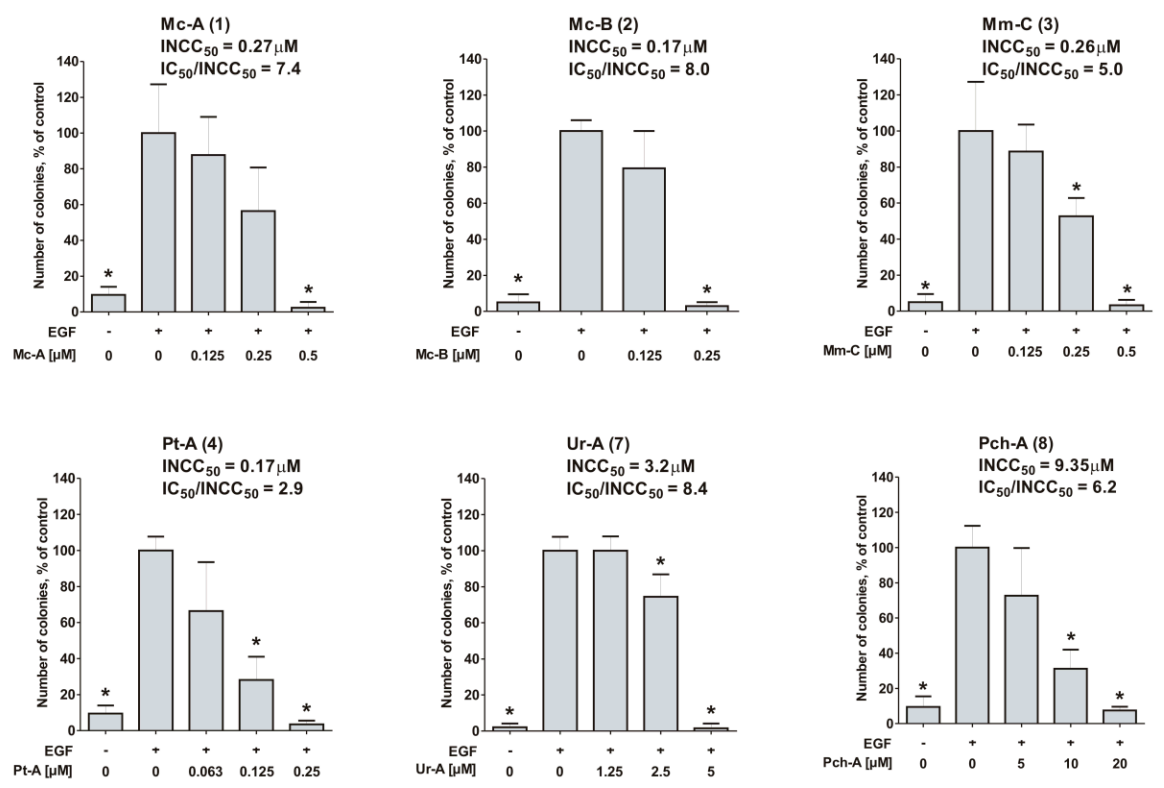

Figure 1. Alkaloids 1-8 and their effect on EGF-induced neoplastic transformation of JB6 $\mathrm{P}^{+} \mathrm{Cl} 14$ cells. (A) Structures of guanidine alkaloids 1-8 isolated from the marine sponge Monanchora pulchra; (B) representative pictures of microscopic fields of EGF-induced colonies of JB6 $\mathrm{P}^{+} \mathrm{Cl} 41$ cells in soft agar treated with urupocidin A (6) at the indicated concentrations; (C) Inhibition of EGF-induced neoplastic transformation of JB6 $\mathrm{P}^{+} \mathrm{Cl} 41$ cells by compounds $\mathbf{1 - 4}, \mathbf{7}$, and $\mathbf{8}$. $\mathrm{INCC}_{50}$-concentration leading to a $50 \%$ inhibition of colonies formation. Ratios of $\mathrm{IC}_{50} / \mathrm{INCC}_{50}$ were calculated using the $\mathrm{IC}_{50}$ values from Table 1 generated by using the MTT assay. ${ }^{*}$ indicates a statistically significant difference $(p<0.05)$ from the control value. 


\section{Results and Discussion}

\subsection{Inhibition of EGF-Induced Malignant Transformation of Murine Epithelial Cells}

First, the ability of the alkaloids 1-4, 7, and 8 to prevent the EGF-induced neoplastic transformation and colony formation was studied using a model of murine epithelial JB6 $\mathrm{P}^{+} \mathrm{Cl} 41$ cells and standard anchorage independent malignant transformation assay $[34,39,40]$. JB6 cells can be sensitive (JB6 $\left.\mathrm{P}^{+}\right)$ or not sensitive $\left(\mathrm{JB} 6 \mathrm{P}^{-}\right)$to tumor promoters, such as EGF or 12-O-tetradecanoylphorbol-13-acetate (TPA), leading to malignant transformation of the cells and resulting in anchorage-independent colony formation upon stimulation with these agents (Figure 1B) [40,41]. Anchorage-independent growth of cancer cells in vitro has been characterized as a hallmark of the tumor phenotype, particularly with respect to metastatic potential (reviewed in [42]). Remarkably, marine substances 1-4, 7, and 8 were able to inhibit EGF-induced malignant transformation and anchorage-independent colony formation of JB6 $\mathrm{P}^{+} \mathrm{Cl} 41$ cells at low micro- and nanomolar concentrations (Figure 1B,C). Interestingly, in these experiments, active concentrations $\left(\mathrm{INCC}_{50}\right)$ were three- to eight-fold lower than the corresponding cytotoxic concentrations (Table 1). In fact, the highest $\mathrm{IC}_{50} / \mathrm{INCC}_{50}$ ratios were observed for compounds 2 and 7 (Figure 1C). This high ratio of $\mathrm{IC}_{50} / \mathrm{INCC}_{50}$ suggests potent cancer-preventive activity of the compound without induction of side effects caused by its cytotoxic properties, although this awaits further confirmation in vivo.

Table 1. $\mathrm{IC}_{50}$ of alkaloids 1-8 in human cancer HeLa cells and mouse non-malignant JB6 $\mathrm{P}^{+} \mathrm{Cl} 41$ cell lines after $48 \mathrm{~h}$ of treatment.

\begin{tabular}{cccc}
\hline \multirow{2}{*}{ No. } & Compound & \multicolumn{2}{c}{ Cytotoxic Activity, IC $\mathbf{5 0}[\boldsymbol{\mu}], \mathbf{4 8 ~ h}$} \\
\cline { 3 - 4 } & & HeLa Cells & JB6 $^{+}$C C141 Cells \\
\hline $\mathbf{1}$ & Monanchocidin A (Mc-A) & 1.39 & 2.01 \\
$\mathbf{2}$ & Monanchocidin B (Mc-B) & 0.58 & 1.36 \\
$\mathbf{3}$ & Monanchomycalin C (Mm-C) & 1.84 & 1.31 \\
$\mathbf{4}$ & Ptilomycalin A (Pt-A) & 1.1 & 0.5 \\
$\mathbf{5}$ & Monanchomycalin B (Mm-B) & 1.5 & 1.72 \\
$\mathbf{6}$ & Normonanchocidin D (nMc-D) & 2.1 & 5.2 \\
$\mathbf{7}$ & Urupocidin A (Ur-A) & 28.7 & 27 \\
$\mathbf{8}$ & Pulchranin A (Pch-A) & 51 & 58 \\
& Cisplatin & 4.75 & 30.2 \\
\hline
\end{tabular}

Note, due to the small amount available, substances 5 and $\mathbf{6}$ were used only in a limited number of experiments. Thus, these compounds were not examined in the current experiments (inhibition of EGF-induced malignant transformation, Figure $1 \mathrm{~B}, \mathrm{C})$, as well as in experiments on AP-1- and p53-dependent transcriptional activities modulations (Figures 2A and Figure 3, correspondently).

(A)
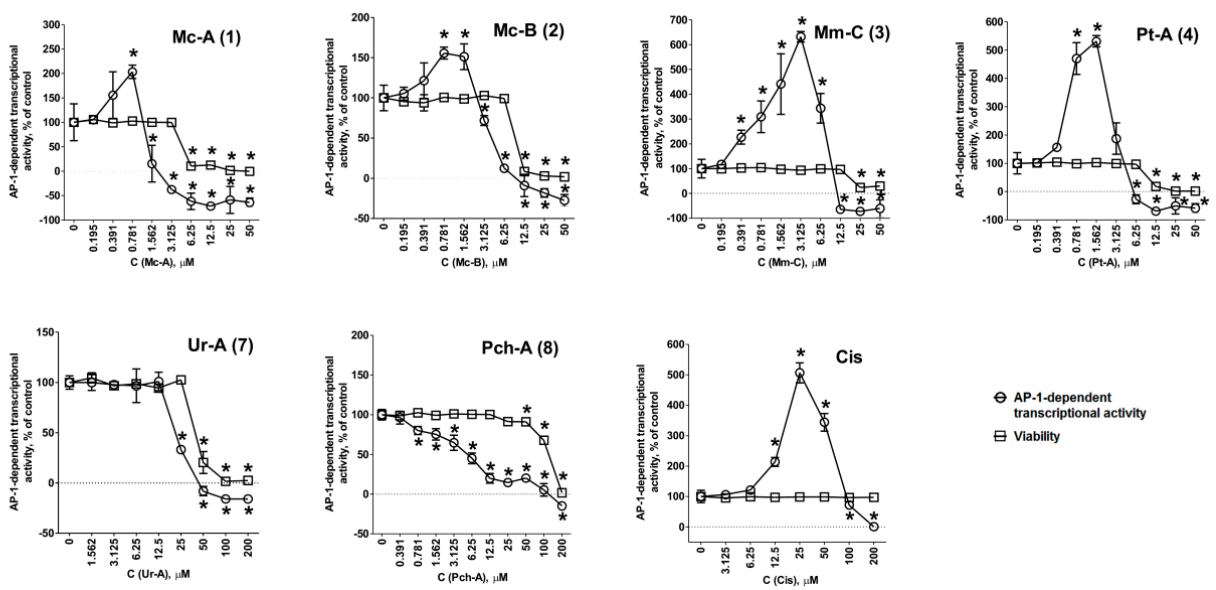
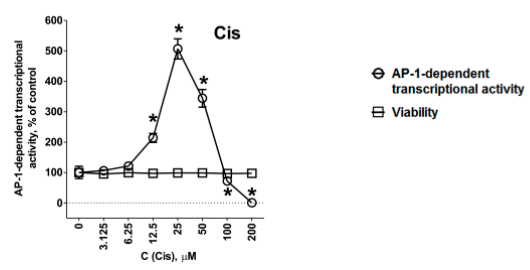

Figure 2. Cont. 
(B)

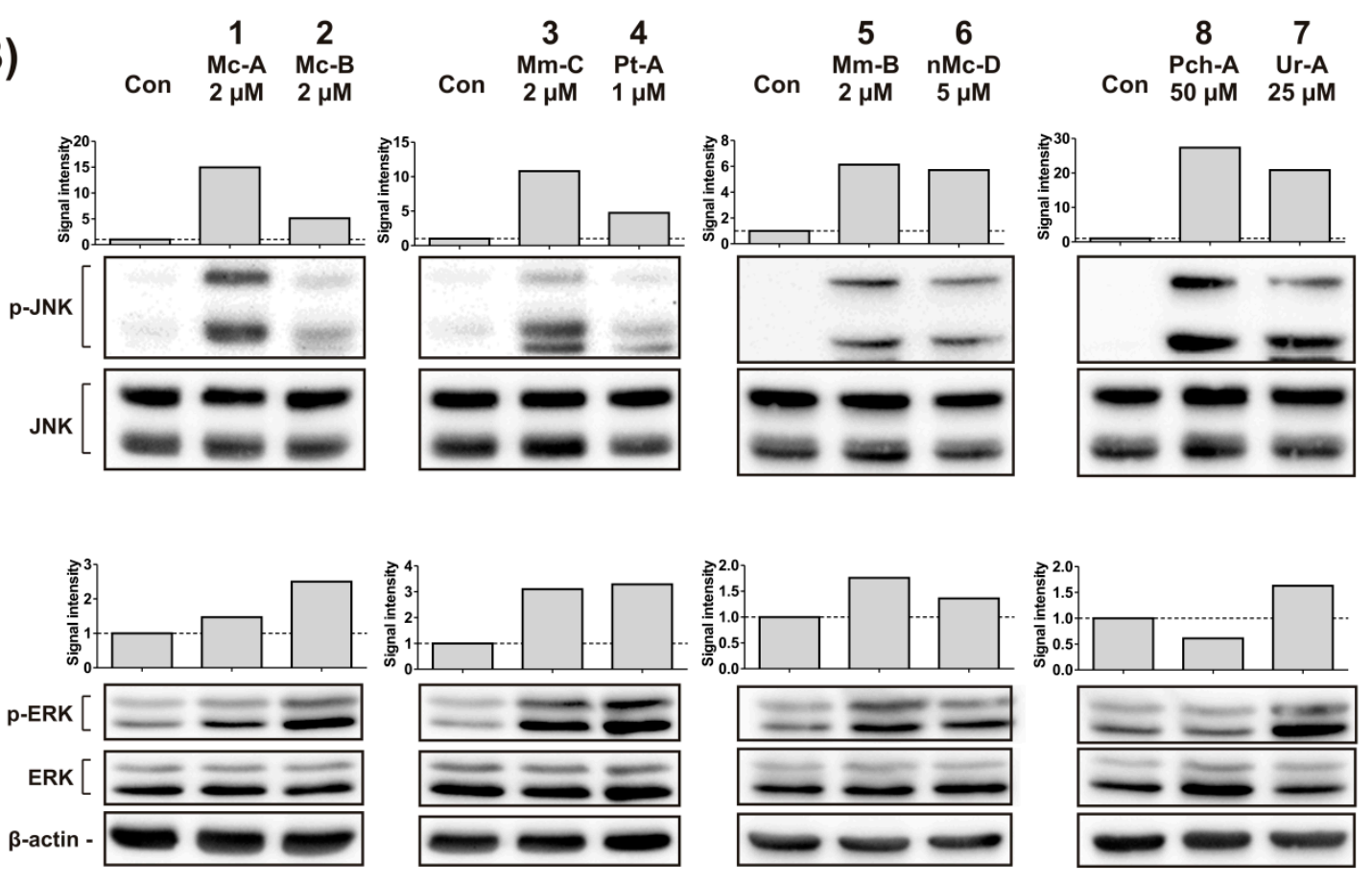

(C)
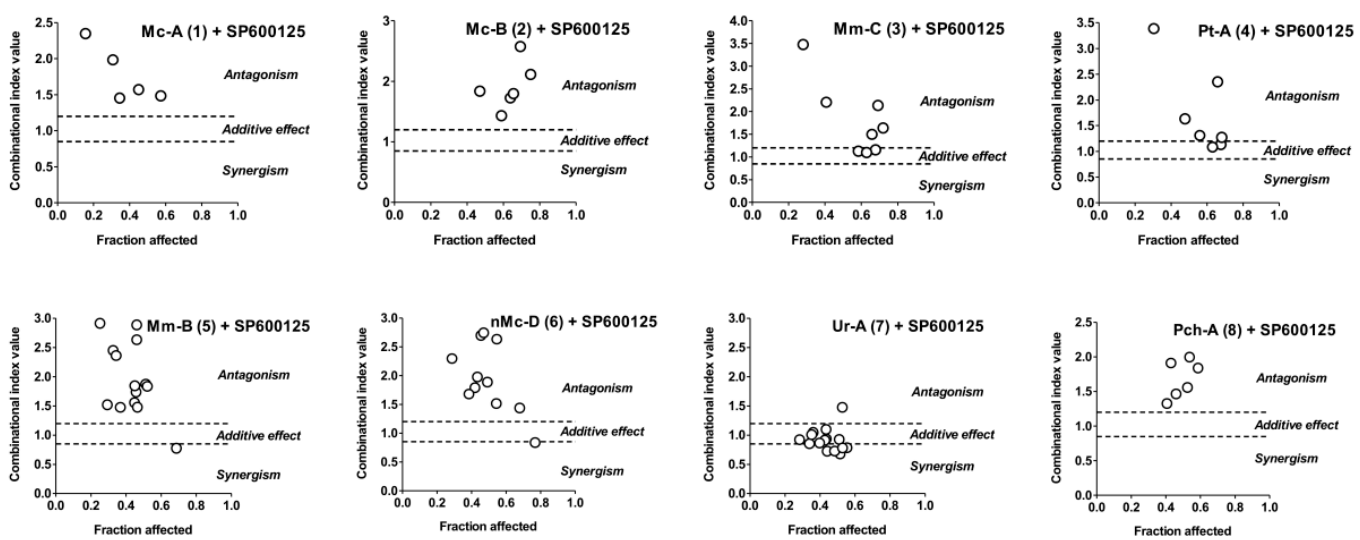

Figure 2. Effect of alkaloids 1-8 on MAPK/AP-1 signaling. (A) Effect on basal AP-1-dependent transcriptional activity $(\bigcirc)$ and viability $(\square)$ of JB6 Cl41 cells stably expressing a luciferase reporter gene controlled by the AP-1 DNA binding sequence after $12 \mathrm{~h}$ of treatment. Cell viability was measured using MTT assay; (B) effect on the activation of JNK1/2 and ERK1/2. JB6 $\mathrm{P}^{+} \mathrm{Cl} 14$ cells were treated with the compounds 1-8 at the indicated concentrations for $48 \mathrm{~h}$, and the level of protein expression was assessed by Western blotting. The intensities of $\mathrm{p}-\mathrm{JNK} 1 / 2$ and $\mathrm{p}-\mathrm{ERK} 1 / 2$ signals were quantified with Quantity One 4.6 software (Bio-Rad, Hercules, CA, USA) and normalized against the signals of total JNK1/2 and ERK1/2, correspondently; and (C) the effect of SP600125 (specific JNK1/2 inhibitor) on the survival of JB6 $\mathrm{P}^{+} \mathrm{Cl} 41$ cells treated with compounds 1-8. Cells were co-treated with different concentrations of the individual drugs or their combination for $48 \mathrm{~h}$. Cell viability was measured by MTT assay and the combinational index (CI) values were calculated with CompuSyn software (v.1.0., ComboSyn Inc., Paramus, NJ, USA) using the Chou-Talalay method. The ratio of the substances and the effects are presented in the Supplementary Materials. * indicates a statistically significant difference $(p<0.05)$ from the control value. 

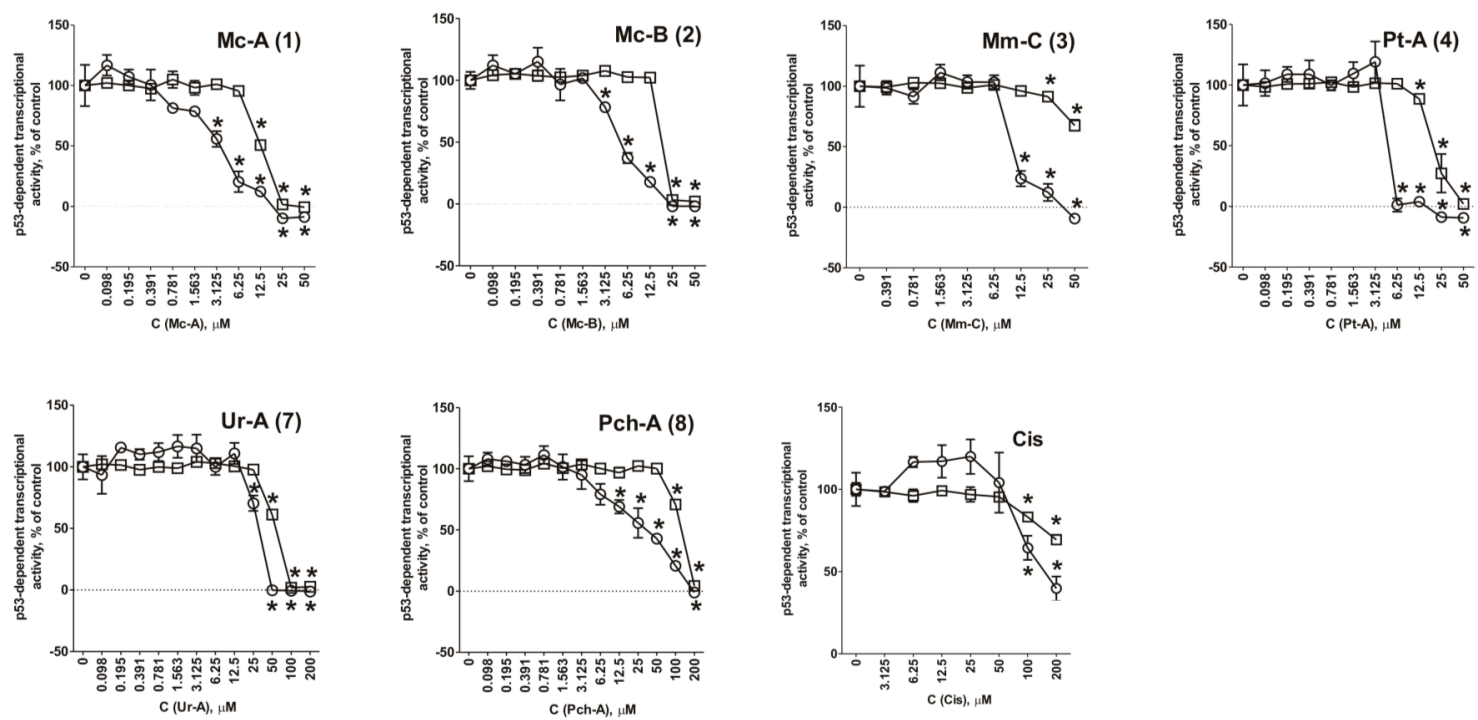

Figure 3. Effect alkaloids 1-8 on basal p53-dependent transcriptional activity ( $\bigcirc)$ and viability ( $\square$ ) of JB6 Cl41 cells stably expressing a luciferase reporter gene controlled by the p53 DNA binding sequence after $12 \mathrm{~h}$ of treatment. Cell viability was measured using MTT assay. * indicates a statistically significant difference $(p<0.05)$ from the control value.

\subsection{Effect on $M A P K / A P-1$ Signaling}

Malignant transformation of JB6 $\mathrm{P}^{+} \mathrm{Cl} 41$ cells involves the activation of the nuclear factor activator protein-1 (AP-1) [43-45], while blocking AP-1-transcriptional activity, can mediate inhibition of EGF-induced cell transformation [44,46,47]. Mitogen-activated protein kinases (MAPK) JNK1/2 and ERK1/2 are well-known upstream players of the AP-1 activation pathway. JNK1/2 and ERK1/2 promote the AP-1 transcriptional factor through the activation of expression and stabilization of Fos and Jun [48-50]. We, therefore, investigated the effects of the sponge alkaloids on MAPK/AP-1 signaling using the well-established model of JB6 C141 cells stably expressing a luciferase reporter gene controlled by an AP-1 binding sequence [35,36,51].

First, we evaluated the effect of the alkaloids 1-4, 7 , and 8 on AP-1-dependent transcriptional activity (Figure 2A). Indeed, pulchranin A (8) potently suppressed AP-1 transcriptional activity with a significant inhibition at non-cytotoxic doses of at least 70 -fold lower than the $\mathrm{IC}_{50}$ of the compound (Table 1). Interestingly, in cells treated with urupocidin A (7), AP-1-dependent transcriptional activity was suppressed concurrently with the reduction of cell viability (Figure 2A). Therefore, we conclude that urupocidin A (7) does not affect AP-1-transcriptional activity in the living cells. Surprisingly, ptilomycalin A-like compounds 1-4 induced AP-1 transcriptional activity at pre-cytotoxic concentrations (after $12 \mathrm{~h}$ of treatment) in stably-transfected JB6 Luc AP-1 cells. Consequently, AP-1 suppression is not involved in the inhibition of EGF-induced malignant transformation by compounds 1-4 and 7 (although it might be involved in the effect of pulchranin A (8)).

In addition, the transcription factor AP-1, apart from malignant transformation, is involved in regulation of a wide range of cellular processes (for review see [48,50,52]). Among others, AP-1 is known to be involved in the induction of programmed death of cancer cells $[48,50,53]$. It was reported that some cancer preventive and cytotoxic natural compounds, including those of terrestrial biological sources (e.g., the anticancer drug vinblastine [54,55], the cancer preventive flavonoids kaempferol and genistein [56], and the anti-inflammatory drug tolfenamic acid [57]) and those of marine origin (e.g., the alkaloids 3- and 10-bromofascaplysins [58], the 3-demethylubiquinone Q2, and its synthetic analogs [33,59], and the cancer preventive terpenoid dactylone [34]), as well as some DNA-damaging agents [60], can activate AP-1. Thus, AP-1 activation in our experiments may be involved in the cytotoxic effects of these drugs (at least for compounds 1-4) (Figure 2A). In line with this, the effects of 
compounds 1-4 were similar to the effect observed upon treatment with cisplatin, which also induced a dose-dependent increment of AP-1 activity at pre-cytotoxic concentrations (Figure 2A). In contrast, alkaloids 7 and $\mathbf{8}$, which did not activate AP-1 were significantly less cytotoxic (Table 1), underlining the pro-apoptotic role of AP-1 activation by guanidine alkaloids.

Next, we evaluated the effects of the compounds on upstream mitogen-activated protein kinases (MAPK) JNK1/2 and ERK1/2 in JB6 $\mathrm{P}^{+}$Cl41 (Figure 2B). We have shown that all compounds, except pulchranin $\mathrm{A}(8)$, at concentrations in the range of the respective $\mathrm{IC}_{50} \mathrm{~s}$ induce activation (phosphorylation) of JNK1/2 and ERK1/2. Pulchranin A (8) did not lead to ERK1/2 activation (Figure 2B). Therefore, we postulate that the kinases JNK1/2 and ERK1/2 are involved in the cellular responses to the drugs 1-8 (with the exception of ERK1/2 for pulchranin A (8)).

To prove the importance of JNK1/2 activation for the cytotoxic effect of the guanidine alkaloids 1-8 we performed combinational assays with the well-established JNK1/2 inhibitor SP600125 (Figure 2C). At the active concentrations, SP600125 itself was cytotoxic for JB6 $\mathrm{P}^{+} \mathrm{Cl} 41$ cells. Therefore, the ability of SP600125 to inhibit (antagonize) the cytotoxic effects of the investigated alkaloids was analyzed using the Chou-Talalay method [61]. We could show that SP600125 is able to antagonize the cytotoxic effect of compounds 1-6 and 8, but not of urupocidin A (7) (Figure 2C), although JNK1/2 activation was observed for this compound as well (Figure 2B). This finding strongly suggests that JNK $1 / 2$ is important for the cytotoxic effect of ptilomycalin A-like guanidine alkaloids (1-6), as well as pulchranin A (8), but not of urupocidin A (7).

\subsection{Role of p53 in Cytotoxic Effect of the Guanidine Alkaloids}

It is known that about $50 \%$ of tumors harbor mutant p53 with abrogated tumor-suppressive function [62]. Thus, compounds which are able to induce apoptosis independently of p53 activity could be useful, especially in the treatment of tumors that have lost their p53 function [62]. To investigate the role of p53 in cytotoxicity of compounds 1-4, 7, and 8 we used a well-established JB6-Luc p53 (PG-13) cell model [35,36,51]. These cells stably express a luciferase reporter gene controlled by the p53 DNA binding sequence. We could not observe any activation of p53-dependent transcriptional activity upon the treatment with any of the compounds 1-4, 7, and 8 (Figure 3). Therefore, we conclude that cell death induced by these alkaloids occurs independently of transcriptional activity of the tumor suppressor protein p53. The observed effects were similar to those induced by cisplatin, which is known to be able to induce p53-independent apoptosis in normal human fibroblasts, as well as in cancer cells [63-66]. Before, crambescidin-816 from the marine sponge Crambe crambe, being structurally similar to ptilomycalin A, was reported to increase the expression of p53 pathway components [28]. However, our current finding suggests that active p53 is not required for cytotoxicity of the guanidine alkaloids 1-4, 7, and 8 and, therefore, we postulate that these compounds may be effective in cells and tumors bearing mutant p53.

\subsection{Induction of Programmed Cell Death and Cell Cycle Arrest in Cancer Cells}

To confirm the relevance of cytotoxic properties of the compounds 1-8 we examined their effects on cell viability (Table 1) and cell cycle progression (Table 2) in human cancer HeLa cells. Ptilomycalin A-like alkaloids 1-6 exhibited comparable cytotoxicities, however, monanchocidin B (2) appeared to be the most active compound in human cancer cells (Table 1). All compounds induced DNA fragmentation in malignant cells, indicating induction of programmed cell death (Figure 4A). Although most of the drugs induced activation of caspase-3/7 in HeLa cells at their respective $\mathrm{IC}_{50} \mathrm{~s}$, these effects were distinctly less pronounced when compared to treatment with the conventional chemotherapeutic agent cisplatin (Figure 4B). These findings support our previous data on induction of non-apoptotic cells death by monanchocidin A (1) in GCT cells [14] and suggest that the structurally-related alkaloids 2-6, as well as the structurally-distinct compounds urupocidin A (7) and pulchranin A (8) may have similar non-apoptotic mechanisms of action. Interestingly, HeLa cells treated with urupocidin A (7) did not exhibit caspase-3/7 activation (Figure 4B), although the percentage of cells containing fragmentated 
DNA was quite high (Figure 4A). This may suggest that caspase-related apoptotic pathways are not involved in the cellular response to urupocidin A (7) at all while, in the case of monanchocidin A (1), we found it to be of minor importance [14].

(A)

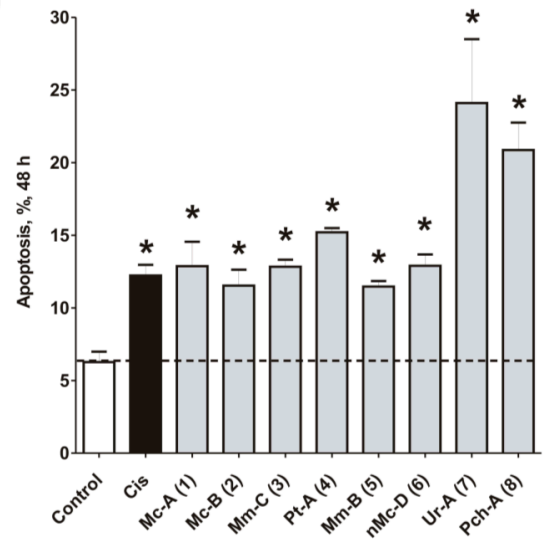

(B)

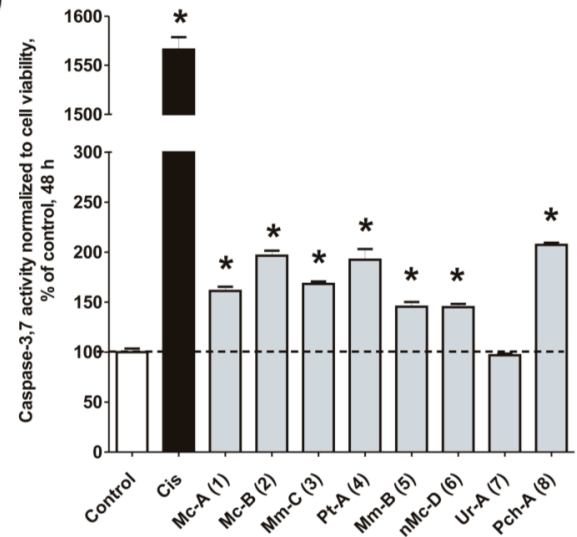

Figure 4. Pro-apoptotic activity of alkaloids 1-8 in human cancer cells. (A) Analysis of DNA fragmentation in HeLa cells treated with compounds 1-8 for $48 \mathrm{~h}$ at the concentrations of $\mathrm{IC}_{50}$. The number of cells with fragmented DNA was assessed with flow cytometry and assumed as the sub-G1 population in cycle analysis; and (B) analysis of caspase-3/7 activity in HeLa cells under the treatment with the compounds 1-8 at the concentrations of $\mathrm{IC}_{50}$ for $48 \mathrm{~h}$. Cisplatin was used as a positive control. Concentrations used corresponded to $\mathrm{IC}_{50}$ for HeLa cells as presented in Table 1. $*$ indicates a statistically significant difference $(p<0.05)$ from the control value.

Interestingly, normonanchocidin D (6), which-in contrast to the compounds 1-5-does not have a spermidine or oxyspermidine motif in its structure, still holds comparable cytotoxic activity (Table 1 , Figures 3 and 4). In addition, the cytotoxic activity of compounds containing spermidine (3-5) or oxyspermidine $(\mathbf{1}, \mathbf{2})$ did not differ significantly from each other. Consequently, we assume that this motif is most likely not important/essential for the cytotoxicity of ptilomycalin A-like compounds. It has been previously suggested before that the presence of spermidine in the molecule of ptilomycalin A-like compounds leads to the inhibition of eIF5A hypusination and, consequently, contributes to cell death or growth suppression [15]. Our present research, therefore, suggests that this speculation was not correct.

Additionally, we investigated the effects of the marine compounds on the cell cycle progression of human cervical carcinoma cells (Table 2). All the ptilomycalin A-like compounds 1-6 induced S-phase arrests, while treatment with urupocidin A (7), having a different chemical structure, induced G2/M-arrest (Table 2). Pulchranin A (8) did not alter cell cycle phase distribution of HeLa cells (Table 2). These data are in line with the previous reported S-phase cell cycle arrest induced by ptilomycalin A-like crambescidin-800 [23], as well as the effects of monanchocidin A on different human cancer cell line [14]. 
Table 2. Cell cycle analysis of human cancer HeLa cells treated with alkaloids $\mathbf{1 - 8}$ at the concentrations of $\mathrm{IC}_{50}$ for $48 \mathrm{~h}$

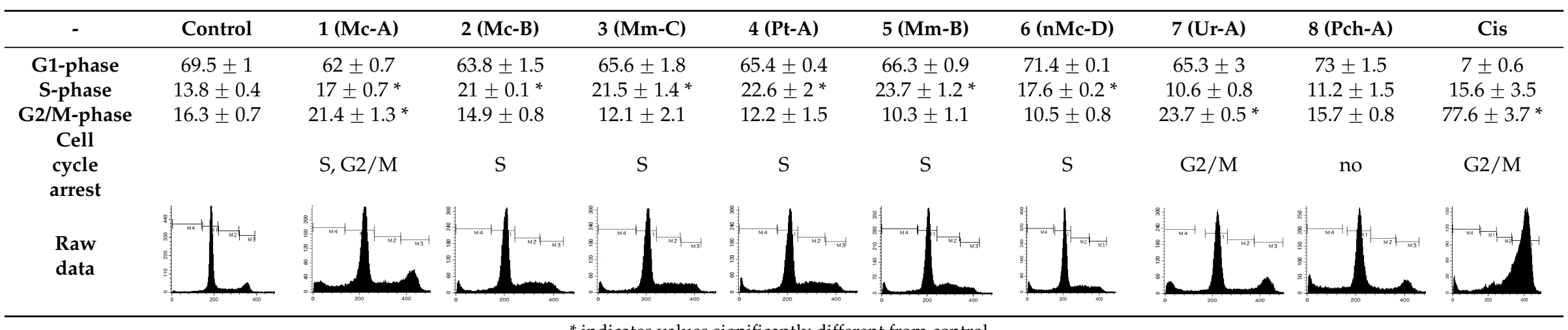

${ }^{*}$ indicates values significantly different from control. 


\section{Materials and Methods}

\subsection{Reagents and Antibodies}

The guanidine alkaloids: monanchocidin A (1) and monanchocidin B (2) [10], monanchomycalin C (3) and ptilomycalin A (4) [17], monanchomycalin B (5) [9], normonanchocidin D (6) [22], urupocidin A (7) [21], and pulchranin A (8) [11] were isolated from marine sponge Monanchora pulchra as described earlier. The sponge was collected in the Sea of Okhotsk (Pacific Ocean, Russian Far East). The precise coordinates of the sponge collections have been published before (see above). The purity of each compound was proved by ${ }^{1} \mathrm{H}$ NMR (nuclear magnetic resonance), MS (mass spectrometry), HPLC (high performance liquid chromatography), and TLC (thin-layer chromatography) data, as well as by measuring of optical rotations. Anisomycin and cisplatin (cis-diamminedichloroplatinum (II), $1 \mathrm{mg} / \mathrm{mL}$ ) were purchased from NeoCorp (Weilheim, Germany), SP600125. Primary and secondary antibodies used were: anti- $\beta$-Actin-HRP (goat pAb, sc-1616, Santa Cruz, 1:10,000), anti-ERK (mouse mAb, \#9107, Cell Signaling Technology, 1:2000), anti-JNK (rabbit mAb, \#9258, Cell Signaling Technology, 1:1000), anti-phospho-ERK (rabbit mAb, \#4377, Cell Signaling Technology, 1:1000) anti-phospho-JNK (rabbit mAb, \#4668 Cell Signaling Technology, 1:1000), secondary anti-mouse IgG-HRP (sheep, NXA931 GE Healthcare, 1:10,000), secondary anti-rabbit IgG-HRP (goat, \#7074, Cell Signaling Technology, 1:5000).

\subsection{Cell Culture}

The human cancer cell line HeLa (cervical carcinoma) was obtained from ATCC (Manassas, VA, USA). The JB6 $\mathrm{P}^{+} \mathrm{Cl} 41$ mouse epidermal cell line and its stable transfectants, JB6-Luc AP-1 and JB6-Luc p53 (PG-13), cells were kindly provided by Prof. Zigang Dong, Hormel Institute, University of Minnesota, $\mathrm{MN}$, USA. Cells were cultured in monolayers at $37^{\circ} \mathrm{C}$ and $5 \% \mathrm{CO}_{2}$ in L-glutamine-supplied RPMI (for HeLa cells) or MEM (for JB6 P+ Cl41, JB6-Luc AP-1, and JB6-Luc p53 cells) media, containing 10\% FBS (fetal bovine serum) and 1\% penicillin/streptomycin (Invitrogen, Paisley, UK). Cells were continuously kept in culture for a maximum of three months, and were routinely inspected microscopically for stable phenotype and regularly checked for contamination with mycoplasma.

\subsection{In Vitro MTT-Based Drug Sensitivity Assay}

Cytotoxicity of the individual compounds was evaluated by MTT assay. Experiments were performed as previously described [67]. In brief, 6000 cells/well were seeded in a 96-well plate, incubated overnight, and treated with the drugs in $100 \mu \mathrm{L} /$ well of fresh media. After $48 \mathrm{~h}$ of treatment cell viability was measured spectrophotometrically using MTT (3-(4,5-dimethylthiazol-2-yl)2,5-diphenyltetrazolium bromide) reagent.

\subsection{Anchorage-Independent Neoplastic Transformation (Colony Growth Assay)}

The cancer preventive activity of alkaloids 1-8 was evaluated using an anchorage-independent neoplastic transformation assay. The experiment was performed as described before [35]. In brief, EGF $\left(10 \mathrm{ng} / \mathrm{mL}\right.$ ) was used to induce neoplastic transformation of JB6 $\mathrm{P}^{+} \mathrm{Cl} 41$ cells. The assay was carried out in six-well tissue culture plates. Mouse JB6 $\mathrm{P}^{+} \mathrm{Cl} 41$ cells $\left(8 \times 10^{3}\right.$ cells $\left./ \mathrm{mL}\right)$ were treated with various concentrations of the compounds in $1 \mathrm{~mL}$ of $0.33 \%$ basal medium Eagle (BME)-agar containing $10 \%$ FBS over $3 \mathrm{~mL}$ of $0.5 \%$ BME-agar containing $10 \%$ FBS and various concentrations of the tested drugs. The plates were incubated at $37^{\circ} \mathrm{C}$ in $5 \% \mathrm{CO}_{2}$ atmosphere for 14 days, following the scoring of cell colonies using an Olympus CKX31 inverted research microscope (Olympus, Center Valley, PA, USA).

\subsection{Determination of the Effect of Compounds on the Basal Transcriptional Activity of AP-1 and p53}

The effect of the marine guanidine alkaloinds on the basal transcriptional activities of AP-1 or p53 was evaluated using JB6 Cl41 cell lines stably expressing a luciferase reporter gene controlled by an AP-1or p53-DNA binding sequence [35,36,51], as described previously, with slight modifications [36]. 
Briefly, cells were pre-incubated overnight in 96-well plates $\left(20 \times 10^{3}\right.$ cells/well $)$ in culture medium (100 $\mathrm{LL} /$ well). Then, the medium was replaced with fresh medium containing different concentrations of compounds. After incubation for $12 \mathrm{~h}$, cells were lysed for $1 \mathrm{~h}$ at RT with lysis buffer $(0.1 \mathrm{M}$ PBS (pH 7.8), 1\% Triton X-100, 1 mM DTT, 2 mM EDTA). Then, $30 \mu \mathrm{L}$ of lysate from each well was transferred into a plate for luminescent analysis, and luciferase activity was measured using luciferase assay D-luciferin-based buffer (100 $\mu \mathrm{L} /$ well) and the Luminoscan Ascent Type 392 microplate reader (Labsystems, Helsinki, Finland).

\subsection{Cell Cycle and DNA Fragmentation Analysis}

The cell cycle distribution was analyzed by flow cytometry using PI staining as described before [68]. In brief, cells were pre-incubated overnight in six-well plates $\left(0.2 \times 10^{6}\right.$ cells/well $)$ and treated with the investigated drugs. After $48 \mathrm{~h}$ of treatment, cells were trypsinized, fixed with $70 \% \mathrm{EtOH} / \mathrm{H}_{2} \mathrm{O}(\mathrm{v} / \mathrm{v})$ at $-20{ }^{\circ} \mathrm{C}$ overnight, stained with buffer containing propidium iodide (PI) and RNase, and analyzed with a BD Bioscience FACS Calibur analyzer (BD Bioscience, Bedford, MA, USA). The data were analyzed using BD Bioscience Cell Quest Pro v.5.2.1. software (BD Bioscience). Cells containing fragmented DNA were detected as a sub-G1 population.

\subsection{Examination of Antagonistic Effects of JNK1/2 Inhibitor SP600125 on the Cytotoxicity of the Tested Compounds}

Determination of synergistic, antagonistic, or additive effects of SP600125 on the activity of investigated compounds were analyzed using the Chou-Talalay method [61]. The experiment was performed as described before with slight modifications $[14,38]$. Drugs were combined in a non-constant molar ratio and the data were generated using MTT assay. Cells were pre-treated for with $20 \mu \mathrm{M}$ or $40 \mu \mathrm{M}$ of SP600125 in the $50 \mu \mathrm{L} /$ well culture media for $1 \mathrm{~h}$. Then, drug-containing or drug-free media was added to wells ( $50 \mu \mathrm{L} /$ well, up to a total volume $100 \mu \mathrm{L} /$ well). Cells were incubated for $48 \mathrm{~h}$ and the cell viability was measured with MTT assay as described above. The combinational index (CI) was calculated with the CompuSyn v.1.0 software (ComboSyn, Inc., Paramus, NJ, USA). Synergism is defined as a $\mathrm{CI}<0.85$, whereas antagonism is defined by a $\mathrm{CI}>1.2$. A CI value of $0.85-1.2$ reflects an additive effect. The amount/dosages of the compounds used for combination treatment are indicated in Supplementary Materials. All experiments were performed in triplicate.

\subsection{Western Blotting}

Preparation of protein extracts for Western blotting was performed as described previously [35]. In brief, for Western blotting, $1 \times 10^{6}$ cells/well were seeded in Petri dishes $(\varnothing 6 \mathrm{~cm}$ TC Dish (Sarstedt, Numbrecht, Germany), $5 \mathrm{~mL} /$ dish), incubated overnight, and treated with drugs for $48 \mathrm{~h}$ in $2 \mathrm{~mL} /$ dish. Cells were harvested using a cell scraper, washed, and lysed with the Western blotting lysis buffer [68]. Lysates were frozen overnight at $-20{ }^{\circ} \mathrm{C}$ and then centrifuged. Protein concentration in the supernatants was determined by Bradford assay [69].

Western blotting was performed as described before [67]. Total protein extracts (20-30 $\mu \mathrm{g} / \mathrm{sample})$ were subjected to electrophoresis in SDS-polyacrylamide gels at $120 \mathrm{~V}$, and transferred from gel to a $0.2 \mu \mathrm{m}$ pore PVDF membrane. The membrane was blocked and incubated with the primary antibody according to the manufacturers' protocol. After washing, the membranes were incubated with the corresponding secondary antibody for $1 \mathrm{~h}$ at RT. Signals were detected using the ECL chemiluminescence system (Thermo Scientific, Rockford, IL, USA) according to the manufacturer's protocol. Relative optical density of the signal intensity of the bands was quantified with Quantity One 4.6 software (Bio-Rad, Hercules, CA, USA). The signals of $\mathrm{p}$-JNK/1/2 and p-ERK1/2 were normalized against the signals of total JNK/1/2 and ERK1/2, correspondingly.

\subsection{Caspase-3/7 Activity Assay}

The enzymatic activity of caspase-3 and -7 were measured using Caspase-Glo ${ }^{\circledR}$ 3/7 Assay Kit (Promega, Madison, WI, USA). Six thousand cells per well were seeded in a 96-well sterile, 
white, flat-bottom plate in $100 \mu \mathrm{L} /$ well and incubated overnight. Then the media was changed with $90 \mu \mathrm{L} /$ well of fresh media containing investigated substances at various concentrations. After $48 \mathrm{~h}$ of treatment enzymatic caspase-3/7 activity or cells viability was measured. To measure caspase-3/7 activity, $90 \mu \mathrm{L} /$ well of Caspase-Glo ${ }^{\circledR} 3 / 7$ reagent was added and the plates were incubated for 1 $\mathrm{h}$ at RT in the dark. The luminescence was measured using an Infinite F200PRO reader (TECAN, Männedorf, Switzerland). Cells viability was measured using MTT assay (see Table 1) with slight modifications: cells were incubated with MTT reagent for $2 \mathrm{~h}$, then the media was carefully aspirated, plates were dried for $1 \mathrm{~h}$ at RT, and $90 \mu \mathrm{L} /$ well of DMSO were added to dissolve the formazan crystals. Then $90 \mu \mathrm{L}$ of formazan/DMSO solution were transferred into new transparent plate and optical density was read with a photometer. The enzymatic activity of caspase- 3 and -7 were normalized to the cell viability at the correspondent concentration of the drug.

\subsection{Statistical Analysis}

Statistical analyses were performed using GraphPad Prism software v. 5.01 (GraphPad Prism software Inc., La Jolla, CA, USA). Data are presented as mean \pm SEM (standard error of the mean). All of the experiments were performed in triplicates and repeated at least three times. The unpaired Student's $t$-test was used for comparison of two groups. Differences were considered to be statistically significant and marked with an asterisk $\left(^{*}\right)$ if $p<0.05$.

\section{Conclusions}

The observed effects are summarized in Table 3 and Figure 5A-C. Ptilomycalin A-like compounds 1-4 activated JNK1/2 and ERK1/2, following AP-1-activation and caused p53-independent programmed cell death and S-phase cell cycle arrest (Figure 5A). Structurally-distinct urupocidin A (7) induced JNK1/2 and ERK1/2 phosphorylation, as well as p53-independent programmed cell death and G2/M-phase cell cycle arrest, however, JNK1/2 activation did not contribute to the cytotoxicity of the alkaloid. Additionally, p53-independent cell death induced by urupocidin A (7) was not accompanied by alteration of AP-1 transcriptional activity, as well as by caspase-3/7 activation. This suggests a distinctly different mechanism of cytotoxic action of urupocidin A (Figure 5B). Another structurally-distinct alkaloid pulchranin A (8) induced JNK1/2 activation leading to p53-independent programmed cell death without cell cycle arrest induction. However, pulchranin A (8) did not activate ERK1/2 and was able to strongly suppress AP-1-transcriptional activity at non-cytotoxic concentrations (Figure 5C). An important finding was the ability of compounds 1-4, 7, and 8 to inhibit the EGF-induced neoplastic transformation of JB6 $\mathrm{P}^{+} \mathrm{Cl} 41$ cells. In summary, our results suggest that guanidine alkaloids from marine sponge Monanchora pulchra hold potential to eliminate human cancer cells, as well as to prevent cancer cell formation and spreading, which awaits further in vivo confirmation. This research provides the very first insight in the mechanisms of action of compounds $\mathbf{2}-\mathbf{8}$ and relative alkaloids in cancer cells.

Table 3. Summary of observed effects of compounds 1-8.

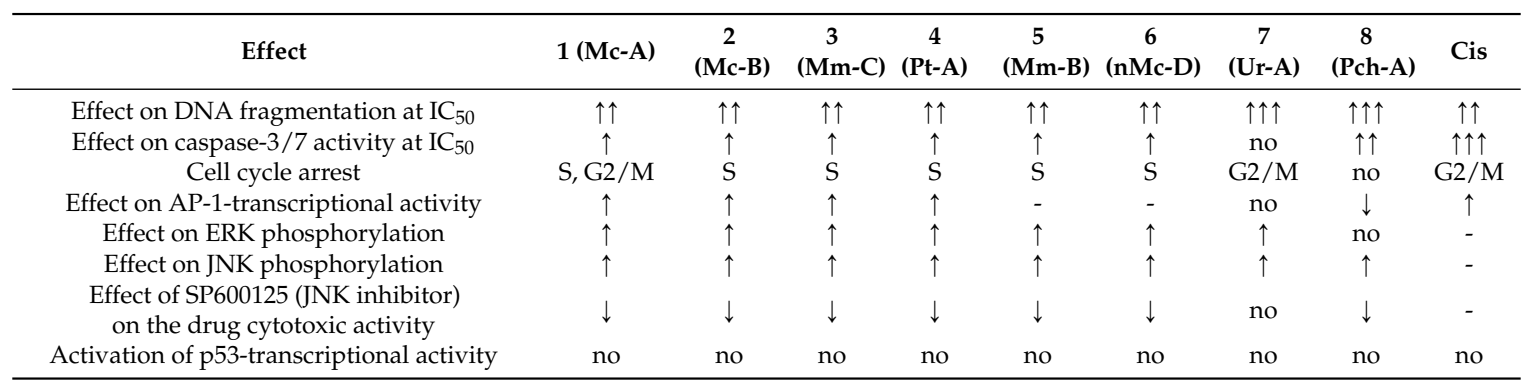

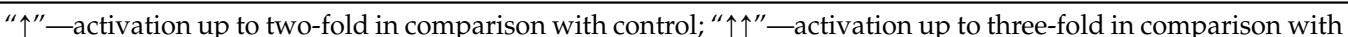

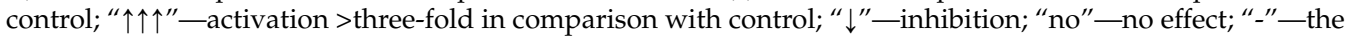
drug was not tested in this assay. 
(A)

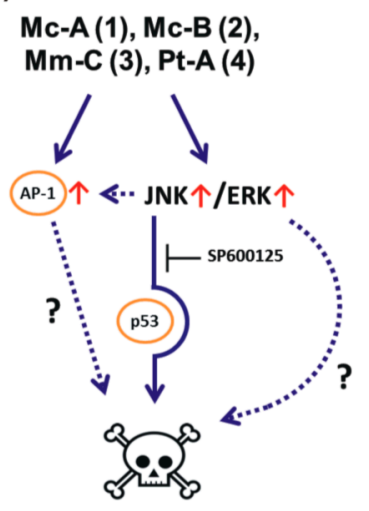

(B)

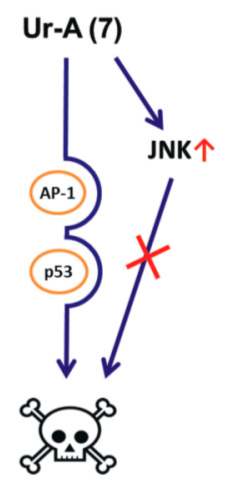

(C)

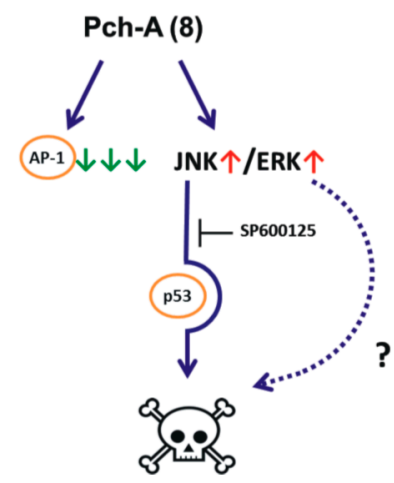

Figure 5. Suggested modes of action of the compounds 1-4 (A); 7 (B); and 8 (C).

Supplementary Materials: The following are available online at www.mdpi.com/1660-3397/14/7/133/s1, the ratio of the substances 1-8 and JNK1/2 inhibitor SP600125 as well as the effects.

Acknowledgments: The research described in this publication was supported by Grant No. 148.2014.4 from the President of RF, Grant 16-03-00553a from RFBR. SD was supported by a scholarship of the Department of Oncology, Hematology, Bone Marrow Transplantation with section Pneumology, Department of Medicine, University Hospital Hamburg-Eppendorf. This research was a part of the project (grant number: 20140513) funded by the Ministry of Oceans and Fisheries, Korea.

Author Contributions: S.A.D. designed and performed the biological experiments. K.M.T., A.G.G., T.N.M. and E.K.K. isolated and purified the investigated compounds. J.H., R.K.S. and K.O. assisted the biological experiments. S.N.F., L.K.S., C.B. and F.H. assisted the results discussion and proofreading. V.A.S. and G.v.A. raised the findings and assisted the research designing and results discussion. The manuscript was written through contributions of all authors. All authors have given approval to the final version of the manuscript. V.A.S and G.v.A. contributed equally.

Conflicts of Interest: The authors declare no conflict of interest.

\section{References}

1. Berlinck, R.G.S.; Burtoloso, A.C.B.; Trindade-Silva, A.E.; Romminger, S.; Morais, R.P.; Bandeira, K.; Mizuno, C.M. The chemistry and biology of organic guanidine derivatives. Nat. Prod. Rep. 2010, 27, 1871-1907. [CrossRef] [PubMed]

2. Abbas, S.; Kelly, M.; Bowling, J.; Sims, J.; Waters, A.; Hamann, M. Advancement into the arctic region for bioactive sponge secondary metabolites. Mar. Drugs 2011, 9, 2423-2437. [CrossRef] [PubMed]

3. Berlinck, R.G.S.; Trindade-Silva, A.E.; Santos, M.F.C. The chemistry and biology of organic guanidine derivatives. Nat. Prod. Rep. 2012, 29, 1382-1406. [CrossRef] [PubMed]

4. Berlinck, R.G.S.; Burtoloso, A.C.B.; Kossuga, M.H. The chemistry and biology of organic guanidine derivatives. Nat. Prod. Rep. 2008, 25, 919-954. [CrossRef] [PubMed]

5. Berlinck, R.G.S.; Kossuga, M.H. Natural guanidine derivatives. Nat. Prod. Rep. 2005, 22, 516-550. [CrossRef] [PubMed]

6. Berlinck, R.G.S. Natural guanidine derivatives. Nat. Prod. Rep. 2002, 19, 617-649. [CrossRef] [PubMed]

7. Hamann, M.T.; Gul, W.; Hammond, N.L.; Yousaf, M.; Bowling, J.J.; Schinazi, R.F.; Wirtz, S.S.; Andrews, G.D.C.; Cuevas, $\mathrm{C}$. Modification at the $\mathrm{C} 9$ position of the marine natural product isoaaptamine and the impact on HIV-1, mycobacterial, and tumor cell activity. Bioorgan. Med. Chem. 2006, 14, 8495-8505.

8. Guzii, A.G.; Makarieva, T.N.; Denisenko, V.A.; Dmitrenok, P.S.; Kuzmich, A.S.; Dyshlovoy, S.A.; Krasokhin, V.B.; Stonik, V.A. Monanchocidin: A new apoptosis-inducing polycyclic guanidine alkaloid from the marine sponge Monanchora pulchra. Org. Lett. 2010, 12, 4292-4295. [CrossRef] [PubMed]

9. Makarieva, T.N.; Tabakmaher, K.M.; Guzii, A.G.; Denisenko, V.A.; Dmitrenok, P.S.; Kuzmich, A.S.; Lee, H.S.; Stonik, V.A. Monanchomycalins A and B, unusual guanidine alkaloids from the sponge Monanchora pulchra. Tetrahedron Lett. 2012, 53, 4228-4231. [CrossRef] 
10. Makarieva, T.N.; Tabakmaher, K.M.; Guzii, A.G.; Denisenko, V.A.; Dmitrenok, P.S.; Shubina, L.K.; Kuzmich, A.S.; Lee, H.S.; Stonik, V.A. Monanchocidins B-E: Polycyclic guanidine alkaloids with potent antileukemic activities from the sponge Monanchora pulchra. J. Nat. Prod. 2011, 74, 1952-1958. [CrossRef] [PubMed]

11. Guzii, A.G.; Makarieva, T.N.; Korolkova, Y.V.; Andreev, Y.A.; Mosharova, I.V.; Tabakmaher, K.M.; Denisenko, V.A.; Dmitrenok, P.S.; Ogurtsova, E.K.; Antonov, A.S.; et al. Pulchranin A, isolated from the far-eastern marine sponge, Monanchora pulchra: The first marine non-peptide inhibitor of TRPV-1 channels. Tetrahedron Lett. 2013, 54, 1247-1250. [CrossRef]

12. Bensemhoun, J.; Bombarda, I.; Aknin, M.; Vacelet, J.; Gaydou, E.M. Ptilomycalin D, a polycyclic guanidine alkaloid from the marine sponge Monanchora dianchora. J. Nat. Prod. 2007, 70, 2033-2035. [CrossRef] [PubMed]

13. Gallimore, W.A.; Kelly, M.; Scheuer, P.J. Alkaloids from the sponge Monanchora unguifera. J. Nat. Prod. 2005, 68, 1420-1423. [CrossRef] [PubMed]

14. Dyshlovoy, S.A.; Hauschild, J.; Amann, K.; Tabakmakher, K.M.; Venz, S.; Walther, R.; Guzii, A.G.; Makarieva, T.N.; Shubina, L.K.; Fedorov, S.N.; et al. Marine alkaloid monanchocidin A overcomes drug resistance by induction of autophagy and lysosomal membrane permeabilization. Oncotarget 2015, 6, 17328-17341. [CrossRef] [PubMed]

15. Dyshlovoy, S.A.; Venz, S.; Hauschild, J.; Tabakmakher, K.M.; Otte, K.; Madanchi, R.; Walther, R.; Guzii, A.G.; Makarieva, T.N.; Shubina, L.K.; et al. Anti-migratory activity of marine alkaloid monanchocidin A-proteomics-based discovery and confirmation. Proteomics 2016, 16, 1590-1603. [CrossRef] [PubMed]

16. Kashman, Y.; Hirsh, S.; McConnell, O.J.; Ohtani, I.; Kusumi, T.; Kakisawa, H. Ptilomycalin A: A novel polycyclic guanidine alkaloid of marine origin. J. Am. Chem. Soc. 1989, 111, 8925-8926. [CrossRef]

17. Tabakmakher, K.M.; Denisenko, V.A.; Guzii, A.G.; Dmitrenok, P.S.; Dyshlovoy, S.A.; Lee, H.S.; Makarieva, T.N. Monanchomycalin $C$, a new pentacyclic guanidine alkaloid from the far-eastern marine sponge Monanchora pulchra. Nat. Prod. Commun. 2013, 8, 1399-1402. [PubMed]

18. Black, G.P.; Coles, S.J.; Hizi, A.; Howard-Jones, A.G.; Hursthouse, M.B.; McGown, A.T.; Loya, S.; Moore, C.G.; Murphy, P.J.; Smith, N.K.; et al. Synthesis and biological activity of analogues of ptilomycalin A. Tetrahedron Lett. 2001, 42, 3377-3381. [CrossRef]

19. Hua, H.M.; Peng, J.; Dunbar, D.C.; Schinazi, R.F.; de Castro Andrews, A.G.; Cuevas, C.; Garcia-Fernandez, L.F.; Kelly, M.; Hamann, M.T. Batzelladine alkaloids from the caribbean sponge Monanchora unguifera and the significant activities against HIV-1 and aids opportunistic infectious pathogens. Tetrahedron 2007, 63, 11179-11188. [CrossRef]

20. Laville, R.; Thomas, O.P.; Berrué, F.; Marquez, D.; Vacelet, J.; Amade, P. Bioactive guanidine alkaloids from two caribbean marine sponges. J. Nat. Prod. 2009, 72, 1589-1594. [CrossRef] [PubMed]

21. Makarieva, T.N.; Ogurtsova, E.K.; Denisenko, V.A.; Dmitrenok, P.S.; Tabakmakher, K.M.; Guzii, A.G.; Pislyagin, E.A.; Es'kov, A.A.; Kozhemyako, V.B.; Aminin, D.L.; et al. Urupocidin A: A new, inducing inos expression bicyclic guanidine alkaloid from the marine sponge Monanchora pulchra. Org. Lett. 2014, 16, 4292-4295. [CrossRef] [PubMed]

22. Tabakmakher, K.M.; Makarieva, T.N.; Denisenko, V.A.; Guzii, A.G.; Dmitrenok, P.S.; Kuzmich, A.S.; Stonik, V.A. Normonanchocidins A, B and D, new pentacyclic guanidine alkaloids from the far-eastern marine sponge Monanchora pulchra. Nat. Prod. Commun. 2015, 10, 913-916. [PubMed]

23. Aoki, S.; Kong, D.; Matsui, K.; Kobayashi, M. Erythroid differentiation in K562 chronic myelogenous cells induced by crambescidin 800, a pentacyclic guanidine alkaloid. Anticancer Res. 2004, 24, 2325-2330. [PubMed]

24. Aron, Z.D.; Pietraszkiewicz, H.; Overman, L.E.; Valeriote, F.; Cuevas, C. Synthesis and anticancer activity of side chain analogs of the crambescidin alkaloids. Bioorg. Med. Chem. Lett. 2004, 14, 3445-3449. [CrossRef] [PubMed]

25. Rubiolo, J.A.; Ternon, E.; Lopez-Alonso, H.; Thomas, O.P.; Vega, F.V.; Vieytes, M.R.; Botana, L.M. Crambescidin- 816 acts as a fungicidal with more potency than crambescidin- 800 and-830, inducing cell cycle arrest, increased cell size and apoptosis in Saccharomyces cerevisiae. Mar. Drugs 2013, 11, 4419-4434. [CrossRef] [PubMed]

26. Berlinck, R.G.; Braekman, J.C.; Daloze, D.; Bruno, I.; Riccio, R.; Ferri, S.; Spampinato, S.; Speroni, E. Polycyclic guanidine alkaloids from the marine sponge Crambe crambe and $\mathrm{Ca}^{++}$channel blocker activity of crambescidin 816. J. Nat. Prod. 1993, 56, 1007-1015. [CrossRef] [PubMed] 
27. Martin, V.; Vale, C.; Bondu, S.; Thomas, O.P.; Vieytes, M.R.; Botana, L.M. Differential effects of crambescins and crambescidin 816 in voltage-gated sodium, potassium and calcium channels in neurons. Chem. Res. Toxicol. 2013, 26, 169-178. [CrossRef] [PubMed]

28. Rubiolo, J.A.; Lopez-Alonso, H.; Roel, M.; Vieytes, M.R.; Thomas, O.; Ternon, E.; Vega, F.V.; Botana, L.M. Mechanism of cytotoxic action of crambescidin-816 on human liver-derived tumour cells. Br. J. Pharmacol. 2014, 171, 1655-1667. [CrossRef] [PubMed]

29. Fedorov, S.; Ermakova, S.; Zvyagintseva, T.; Stonik, V. Anticancer and cancer preventive properties of marine polysaccharides: Some results and prospects. Mar. Drugs 2013, 11, 4876-4901. [CrossRef] [PubMed]

30. Stonik, V.; Fedorov, S. Marine low molecular weight natural products as potential cancer preventive compounds. Mar. Drugs 2014, 12, 636-671. [CrossRef] [PubMed]

31. Fedorov, S.N.; Bode, A.M.; Stonik, V.A.; Gorshkova, I.A.; Schmid, P.C.; Radchenko, O.S.; Berdyshev, E.V.; Dong, Z.G. Marine alkaloid polycarpine and its synthetic derivative dimethylpolyearpine induce apoptosis in JB6 cells through p53-and caspase 3-dependent pathways. Pharm. Res. 2004, 21, 2307-2319. [CrossRef] [PubMed]

32. Fedorov, S.N.; Makarieva, T.N.; Guzii, A.G.; Shubina, L.K.; Kwak, J.Y.; Stonik, V.A. Marine two-headed sphingolipid-like compound rhizochalin inhibits EGF-induced transformation of JB6 $\mathrm{P}^{+} \mathrm{Cl} 41$ cells. Lipids 2009, 44, 777-785. [CrossRef] [PubMed]

33. Fedorov, S.N.; Radchenko, O.S.; Shubina, L.K.; Balaneva, N.N.; Bode, A.M.; Stonik, V.A.; Dong, Z. Evaluation of cancer-preventive activity and structure-activity relationships of 3-demethylubiquinone Q2, isolated from the ascidian aplidium glabrum, and its synthetic analogs. Pharm. Res. 2006, 23, 70-81. [CrossRef] [PubMed]

34. Fedorov, S.N.; Shubina, L.K.; Bode, A.M.; Stonik, V.A.; Dong, Z.G. Dactylone inhibits epidermal growth factor-induced transformation and phenotype expression of human cancer cells and induces G1/S arrest and apoptosis. Cancer Res. 2007, 67, 5914-5920. [CrossRef] [PubMed]

35. Dyshlovoy, S.A.; Fedorov, S.N.; Kalinovsky, A.I.; Shubina, L.K.; Bokemeyer, C.; Stonik, V.A.; Honecker, F. Mycalamide A shows cytotoxic properties and prevents EGF-induced neoplastic transformation through inhibition of nuclear factors. Mar. Drugs 2012, 10, 1212-1224. [CrossRef] [PubMed]

36. Dyshlovoy, S.A.; Fedorov, S.N.; Shubina, L.K.; Kuzmich, A.S.; Bokemeyer, C.; Keller-von Amsberg, G.; Honecker, F. Aaptamines from the marine sponge Aaptos sp. Display anticancer activities in human cancer cell lines and modulate AP-1-, NF-kappa B-, and p53-dependent transcriptional activity in mouse JB6 Cl41 cells. Biomed. Res. Int. 2014, 2014, 1-7. [CrossRef] [PubMed]

37. Fedorov, S.; Dyshlovoy, S.; Monastyrnaya, M.; Shubina, L.; Leychenko, E.; Kozlovskaya, E.; Jin, J.O.; Kwak, J.Y.; Bode, A.M.; Dong, Z.G.; et al. The anticancer effects of actinoporin rtx-a from the sea anemone Heteractis crispa (=Radianthus macrodactylus). Toxicon 2010, 55, 811-817. [CrossRef] [PubMed]

38. Dyshlovoy, S.A.; Menchinskaya, E.S.; Venz, S.; Rast, S.; Amann, K.; Hauschild, J.; Otte, K.; Kalinin, V.I.; Silchenko, A.S.; Avilov, S.A.; et al. The marine triterpene glycoside frondoside A exhibits activity in vitro and in vivo in prostate cancer. Int. J. Cancer 2016, 138, 2450-2465. [CrossRef] [PubMed]

39. Colburn, N.H.; Gindhart, T.D. Specific binding of transforming growth factor correlates with promotion of anchorage independence in EGF receptorless mouse JB6 cells. Biochem. Biophys. Res. Commun. 1981, 102, 799-807. [CrossRef]

40. Colburn, N.H.; Former, B.F.; Nelson, K.A.; Yuspa, S.H. Tumour promoter induces anchorage independence irreversibly. Nature 1979, 281, 589-591. [CrossRef] [PubMed]

41. Colburn, N.H.; Koehler, B.A.; Nelson, K.J. A cell culture assay for tumor-promoter-dependent progression toward neoplastic phenotype: Detection of tumor promoters and promotion inhibitors. Teratog. Carcinog. Mutagen. 1980, 1, 87-96. [CrossRef] [PubMed]

42. Mori, S.; Chang, J.T.; Andrechek, E.R.; Matsumura, N.; Baba, T.; Yao, G.; Kim, J.W.; Gatza, M.; Murphy, S.; Nevins, J.R. Anchorage-independent cell growth signature identifies tumors with metastatic potential. Oncogene 2009, 28, 2796-2805. [CrossRef] [PubMed]

43. Huang, C.S.; Ma, W.Y.; Young, M.R.; Colburn, N.; Dong, Z.G. Shortage of mitogen-activated protein kinase is responsible for resistance to AP-1 transactivation and transformation in mouse JB6 cells. Proc. Natl. Acad. Sci. USA 1998, 95, 156-161. [CrossRef] [PubMed]

44. Dong, Z.G.; Birrer, M.J.; Watts, R.G.; Matrisian, L.M.; Colburn, N.H. Blocking of tumor promoter-induced AP-1 activity inhibits induced transformation in JB6 mouse epidermal cells. Proc. Natl. Acad. Sci. USA 1994, 91, 609-613. [CrossRef] [PubMed] 
45. Huang, C.S.; Ma, W.Y.; Dawson, M.I.; Rincon, M.; Flavell, R.A.; Dong, Z.G. Blocking activator protein-1 activity, but not activating retinoic acid response element, is required for the antitumor promotion effect of retinoic acid. Proc. Natl. Acad. Sci. USA 1997, 94, 5826-5830. [CrossRef] [PubMed]

46. Hsu, T.C.; Nair, R.; Tulsian, P.; Camalier, C.E.; Hegamyer, G.A.; Young, M.R.; Colburn, N.H. Transformation nonresponsive cells owe their resistance to lack of p65/nuclear factor-kappa B activation. Cancer Res. 2001, 61, 4160-4168. [PubMed]

47. Li, J.J.; Westergaard, C.; Ghosh, P.; Colburn, N.H. Inhibitors of both nuclear factor-kappa beta and activator protein-1 activation block the neoplastic transformation response. Cancer Res. 1997, 57, 3569-3576. [PubMed]

48. Shaulian, E.; Karin, M. AP-1 as a regulator of cell life and death. Nat. Cell Biol. 2002, 4, E131-E136. [CrossRef] [PubMed]

49. Karin, M. The regulation of AP-1 activity by mitogen-activated protein kinases. J. Biol. Chem. 1995, 270, 16483-16486. [CrossRef] [PubMed]

50. Eferl, R.; Wagner, E.F. AP-1: A double-edged sword in tumorigenesis. Nat. Rev. Cancer 2003, 3, 859-868. [CrossRef] [PubMed]

51. Fedorov, S.N.; Shubina, L.K.; Kicha, A.A.; Ivanchina, N.V.; Kwak, J.Y.; Jin, J.O.; Bode, A.M.; Dong, Z.G.; Stonik, V.A. Proapoptotic and anticarcinogenic activities of leviusculoside G from the starfish Henricia leviuscula and probable molecular mechanism. Nat. Prod. Commun. 2008, 3, 1575-1580.

52. Foletta, V.C.; Segal, D.H.; Cohen, D.R. Transcriptional regulation in the immune system: All roads lead to AP-1. J. Leukoc. Biol. 1998, 63, 139-152. [PubMed]

53. Ameyar, M.; Wisniewska, M.; Weitzman, J.B. A role for AP-1 in apoptosis: The case for and against. Biochimie 2003, 85, 747-752. [CrossRef] [PubMed]

54. Berry, A.; Goodwin, M.; Moran, C.L.; Chambers, T.C. AP-1 activation and altered AP-1 composition in association with increased phosphorylation and expression of specific Jun and Fos family proteins induced by vinblastine in KB-3 cells. Biochem. Pharmacol. 2001, 62, 581-591. [CrossRef]

55. Fan, M.; Goodwin, M.E.; Birrer, M.J.; Chambers, T.C. The c-Jun NH(2)-terminal protein kinase/AP-1 pathway is required for efficient apoptosis induced by vinblastine. Cancer Res. 2001, 61, 4450-4458. [PubMed]

56. Gopalakrishnan, A.; Xu, C.J.; Nair, S.S.; Chen, C.; Hebbar, V.; Kong, A.N. Modulation of activator protein-1 (AP-1) and MAPK pathway by flavonoids in human prostate cancer PC3 cells. Arch. Pharm. Res. 2006, 29, 633-644. [CrossRef] [PubMed]

57. Lee, S.H.; Bahn, J.H.; Whitlock, N.C.; Baek, S.J. Activating transcription factor 2 (ATF2) controls tolfenamic acid-induced atf3 expression via map kinase pathways. Oncogene 2010, 29, 5182-5192. [CrossRef] [PubMed]

58. Kuzmich, A.S.; Fedorov, S.N.; Shastina, V.V.; Shubina, L.K.; Radchenko, O.S.; Balaneva, N.N.; Zhidkov, M.E.; Park, J.I.; Kwak, J.Y.; Stonik, V.A. The anticancer activity of 3-and 10-bromofascaplysins is mediated by caspase-8,-9,-3-dependent apoptosis. Bioorgan. Med. Chem. 2010, 18, 3834-3840. [CrossRef] [PubMed]

59. Shubina, L.K.; Fedorov, S.N.; Radchenko, O.S.; Balaneva, N.N.; Kolesnikova, S.A.; Dmitrenok, P.S.; Bode, A.; Dong, Z.; Stonik, V.A. Desmethylubiquinone Q2 from the far-eastern ascidian Aplidium glabrum: Structure and synthesis. Tetrahedron Lett. 2005, 46, 559-562. [CrossRef]

60. Kasibhatla, S.; Brunner, T.; Genestier, L.; Echeverri, F.; Mahboubi, A.; Green, D.R. DNA damaging agents induce expression of fas ligand and subsequent apoptosis in T lymphocytes via the activation of NF-kappa B and AP-1. Mol. Cell 1998, 1, 543-551. [CrossRef]

61. Chou, T.C.; Talalay, P. Quantitative analysis of dose-effect relationships: The combined effects of multiple drugs or enzyme inhibitors. Adv. Enzyme Regul. 1984, 22, 27-55. [CrossRef]

62. Yu, Q. Restoring p53-mediated apoptosis in cancer cells: New opportunities for cancer therapy. Drug Resist. Updates Rev. Comment. Antimicrob. Anticancer Chemother. 2006, 9, 19-25. [CrossRef] [PubMed]

63. McKay, B.C.; Becerril, C.; Ljungman, M. P53 plays a protective role against UV- and cisplatin-induced apoptosis in transcription-coupled repair proficient fibroblasts. Oncogene 2001, 20, 6805-6808. [CrossRef] [PubMed]

64. Konstantakou, E.G.; Voutsinas, G.E.; Karkoulis, P.K.; Aravantinos, G.; Margaritis, L.H.; Stravopodis, D.J. Human bladder cancer cells undergo cisplatin-induced apoptosis that is associated with p53-dependent and p53-independent responses. Int. J. Oncol. 2009, 35, 401-416. [PubMed]

65. Zamble, D.B.; Jacks, T.; Lippard, S.J. P53-dependent and -independent responses to cisplatin in mouse testicular teratocarcinoma cells. Proc. Natl. Acad. Sci. USA 1998, 95, 6163-6168. [CrossRef] [PubMed] 
66. Jacobsen, C.; Honecker, F. Cisplatin resistance in germ cell tumours: Models and mechanisms. Andrology 2014, 3, 111-121. [CrossRef] [PubMed]

67. Dyshlovoy, S.A.; Venz, S.; Shubina, L.K.; Fedorov, S.N.; Walther, R.; Jacobsen, C.; Stonik, V.A.; Bokemeyer, C.; Balabanov, S.; Honecker, F. Activity of aaptamine and two derivatives, demethyloxyaaptamine and isoaaptamine, in cisplatin-resistant germ cell cancer. J. Proteom. 2014, 96, 223-239. [CrossRef] [PubMed]

68. Dyshlovoy, S.A.; Naeth, I.; Venz, S.; Preukschas, M.; Sievert, H.; Jacobsen, C.; Shubina, L.K.; Gesell Salazar, M.; Scharf, C.; Walther, R.; et al. Proteomic profiling of germ cell cancer cells treated with aaptamine, a marine alkaloid with antiproliferative activity. J. Proteome Res. 2012, 11, 2316-2330. [CrossRef] [PubMed]

69. Bradford, M.M. A rapid and sensitive method for the quantitation of microgram quantities of protein utilizing the principle of protein-dye binding. Anal. Biochem. 1976, 72, 248-254. [CrossRef]

(C) 2016 by the authors; licensee MDPI, Basel, Switzerland. This article is an open access article distributed under the terms and conditions of the Creative Commons Attribution (CC-BY) license (http://creativecommons.org/licenses/by/4.0/). 